\title{
Rancang Bangun Sistem Monitoring PH dan Suhu Air pada Akuaponik Berbasis Internet of Thing (IoT)
}

\section{Design of Monitoring System for PH and Water Temperature in Aquaponic Base on Internet of Thing (IoT)}

\author{
Dini Megawati $^{1 *}$, Kholidiyah Masykuroh², Danny Kurnianto ${ }^{3}$ \\ 1,2,3 Program Studi D3 Teknik Telekomunikasi, Fakultas Teknik Telekomunikasi dan Elektro, IT Telkom \\ Purwokerto \\ Jl. DI, Panjaitan No.128 Purwokerto, Jawa Tengah 53147 \\ 16201084@ittelkom-pwt.ac.id ${ }^{1 *}$
}

\begin{abstract}
Abstrak - Akuaponik yang menyatukan sistem budidaya tanaman hidroponik dengan ternak ikan sangat pesat belakangan ini karena menghemat lahan yang digunakan. Sistem akuaponik yang dibahas pada paper ini menggunakan ikan lele dan tanaman kangkung sebagai kombinasi akualtur dan hidroponik dalam lingkungan yang bersifat simbiotik mutualisme. Pada pembudidayaan sistem akuaponik ini dibutuhkan perhatian yang lebih terhadap air, karena air menjadi faktor penting dalam pertumbuhan ikan dan tanaman pada akuaponik. Hal yang perlu diperhatikan yaitu kadar keasaman dan suhu air. Selama ini para pemilik akuaponik masih menggunakan cara manual dalam memonitoring kadar air. Pada penelitian ini penulis membuat solusi suatu kontrol kondisi air menggunakan sensor pH dan suhu berbasis Internet of Things yang menggunakan Arduino Uno sebagai pengontrol mikropengendali, sensor pH digunakan untuk mendeteksi kadar keasaman air, sensor suhu untuk pembacaan suhu menggunakan DS18b20, dan Wemos D1 Mini sebagai interface wifi untuk mengirim data ke firebase. Aplikasi MIT App Inventor digunakan untuk menampilkan data di smartphone pengguna. Dari hasil pengujian akurasi sensor pH air asam didapatkan rata-rata erorr sebesar 7,77\%, air murni rata-rata erorr sebesar 6,97\%, dan air basa rata-rata erorr sebesar 2,59\%. Hasil pengujian akurasi sensor suhu air panas didapatkan rata-rata erorr sebesar 1,59\%, air normal rata rata erorr 1,40\%, dan suhu air panas didapatkan rata-rata erorr 1,02\%.
\end{abstract}

Kata Kunci: Akuaponik, Internet of Things, Arduino UNO, Wemos D1 Min.

\begin{abstract}
Aquaponics, which combines hydroponic cultivation systems with fish farming, is swift recently because it saves land. In this aquaponics system, catfish and kale are used to combine accumulation and hydroponics in a symbiotic mutualism environment. This aquaponics cultivation system requires more attention, such as water and temperature conditions. Water is an essential factor in the growth of fish and plants in aquaponics. Things that need to be considered are the acidity and the temperature of the water. Mostly, aquaponics owners still use manual methods to monitor water levels. In this paper, we controlled the water condition using a $\mathrm{pH}$ and temperature sensor. This system is based on the Internet of Things that using Arduino Uno as a microcontroller controller, a pH sensor used to detect water acidity, and a temperature sensor (DS18b20) for temperature reading, and Wemos D1 Mini as a wifi interface for sending data to Firebase, and the MIT App Inventor application as an application for display on the user's smartphone. Based on the results, the accuracy of the pH sensor for acidic water is $7.77 \%$ of error, pure
\end{abstract} TELKA, Vol.6, No.2, November 2020, pp. 124 137 
water had an average error of $6.97 \%$, and alkaline water had an average error $2.59 \%$. The results of testing the accuracy of the hot water temperature sensor obtained an average error of $1.59 \%$, normal water had an average error of $1.40 \%$, and the temperature of hot water obtained an average error of $1.02 \%$.

Keywords: Aquaponics, Internet of Things, Arduino UNO, Wemos DI Mini.

\section{Pendahuluan}

Perkembangan teknologi dalam bidang pertanian saat ini ditandai salahsatunya dengan munculnya sistem akuaponik yang menggabungkan sistem bercocok tanam dengan budidaya ikan dengan menggunakan lahan yang tidak terlalu luas[1]. Lokasi budidaya yang yang jauh dari rumah menimbulkan persolaan dalam memonitoring kondisi dari tempat budidaya tersebut. Kondisi tempat budidaya ikan dan tanaman pada umunya diukur melalui tingkat $\mathrm{PH}$ dan suhu air[2]. Karena dengan nilai PH dan suhu air tersebut mempengaruhi daur hidup ikan dan tanaman yang dibudidayakan [3]. Penelitian ini bertujuan untuk membuat sistem monitoring PH dan suhu air pada akuaponik, dengan tujuan dapat diterapkan pada budidaya ikan dan tanaman dengan lahan yang lebih luas [4].

Akuaponik adalah sistem pertanian berkelanjutan yang mengkombinasikan akualtur dan hidroponik dalam lingkungan yang bersifat simbiotik. Dalam sistem akuaponik, ikan dan tanaman akan dipelihara secara bersama-sama dan akan bersimbiosis mutualisme. Tanaman memperoleh nutrisi dari kolam dan limbah kotoran ikan, sedangkan ikan mendapat media hidup di air yang bersih setelah dibersihkan oleh tanaman. Limbah kotoran ikan banyak mengandung zat amoniak yang dapat diubah oleh cacing dan mikroba di sekitar akar tanaman menjadi zat lain. Zat lain inilah yang dijadikan nutrisi yang dibutuhkan oleh tumbuhan [3].

Prinsip dasar akuaponik adalah sisa pakan dan kotoran ikan yang memperburuk kualitas air dan menyebabkan kematian pada ikan, akan dimanfaatkan sebagai pupuk bagi tanaman. Pemanfaatan tersebut melalui sistem resirkulasi air kolam yang disalurkan ke media tanaman, yang secara mutualistis juga menyaring air tersebut sehingga saat kembali ke kolam menjadi bersih dari amonia dan mempunyai kondisi yang lebih layak untuk budidaya ikan [5]. Ikan yang digunakan dalam sistem akuaponik ini adalah ikan lele, karena ikan lele menghasilkan kotoran dan sisa-sisa makanan yang jumlahnya lebih banyak, sehingga bisa dimanfaatkan untuk nutrisi bagi tanaman. Tanaman yang digunakan dalam sistem akuaponik ini adalah tanaman kangkung, karena dalam pemeliharaan kangkung memerlukan suplai air secara berkelanjutan dan umur panen kangkung relatif cepat [6][7][8].

Air sebagai media pemeliharaan ikan harus selalu diperhatikan kualitasnya karena sangat berpengaruh terhadap produktifitas hewan akuatik. Ikan lele berkembang dengan baik pada suhu antara 25 hingga 28 derajat Celcius serta $\mathrm{pH}$ 6,5 - 9. Sedangkan tanaman hidroponik memiliki laju pertumbuhan dan kelangsungan hidup tanaman hidrponik yang dipengaruhi oleh 6 faktor penting, diantaranya adalah suhu dan $\mathrm{pH}$ air. Pada umumnya $\mathrm{pH}$ ideal untuk tanaman hidroponik adalah 7,0. Apabila pH ideal, maka akar tanaman dapat menyerap dengan baik nutrisi dan makanan yang dibutuhkan [9].

Oleh karena itu, sistem akuaponik ini membutuhkan beberapa perawatan penting seperti pengecekan kadar $\mathrm{pH}$ dan suhu air yang membutuhkan tenaga yang cukup untuk hadir ditempat kolam akuaponik untuk melakukan proses perawatan. Teknologi Internet of Things (IoT) menjawab permasalahan diatas untuk mengatasi proses perawatan yang membutuhkan waktu lebih, dan teknologi IoT akan meringankan beberapa proses perawatan diantaranya adalah pemantauan kadar $\mathrm{pH}$ dan suhu pada kolam akuaponik [10].

Penelitian [11] bertujuan untuk mengatur status pompa otomatis menggunakan relay, dan komponen lain yang digunakan pada penelitian ini adalah sensor Suhu air DS18B20, sensor kelembaban tanah, mikrokontroler dan sebuah bluetooth yang digunakan sebagai media transmisi ke perangkat android agar user dapat melihat hasil monitoring dari sistem akuaponik. Hasil penelitian ini mikrokontroler sebagai otaknya yang telah memprogram hasil inputan dari sensorsensor, modul bluethooth dan modul relay dapat bekerja dengan baik sebagai pengontrol sistem 
secara cerdas untuk akuaponik dan terintregasi dengan smartphone android menggunakan media transmisi bluethooth [11].

Penelitian [12] membahas tentang memberikan perawatan dengan melakukan pemantauan kadar $\mathrm{pH}$ dan suhu kolam, serta pemberian makan otomatis. Perancangan alat ini menggunakan beberapa sensor yang akan terhubung dengan Node MCU. Alat ini bekerja sebagai monitoring yang mana sensor $\mathrm{pH}$ dan sensor Suhu akan mengirimkan data ke Node MCU dan firebase kemudian dari web mengambil data untuk ditampilkan kepada user, sedangkan Alat servo digunakan pada perancangan alat ini sebagai kontrolling melakukan pemberian ikan yang akan dikontrol secara jarak jauh dengan sistem buka tutup pakan ikan[13].

\section{Metode Penelitian}

\subsection{Prancangan Blok Diagram}

Perancangan sistem terdiri dari perancangan perangkat keras dan perangkat lunak. Alat yang digunakan adalah Arduino Uno sebagai mikrokontroler, sensor $\mathrm{pH}$ sebagai pendeteksi kualitas air di dalam akuaponik dan sensor suhu sebagai pendeteksi suhu di dalam akuaponik. Wemos D1 Mini disini sebagai interface wifi untuk menyambungkan ke firebase. Blok diagram sistem perangkat keras ditunjukan pada Gambar 1.

Pada diagram blok perancangan sistem monitoring $\mathrm{pH}$ dan suhu pada akuaponik yang menjadi otaknya adalah Arduino. Sensor $\mathrm{pH}$ dan sensor suhu dallas ds18b20 merupakan input yang mana sensor $\mathrm{pH}$ dan suhu mengirim data ke Arduino untuk diproses dan data tersebut akan diteruskan menuju output yang telah diproses di Arduino. Output nya yaitu Motor Servo, motor servo akan bekerja untuk sensor $\mathrm{pH}$ yang mana sistem nya up dan down dari cairan $\mathrm{pH}$ yang tersedia, motor servo akan bekerja sesuai perintah yang ditentukan oleh Arduino. Data yang telah diterima oleh Arduino dari beberapa sensor tersebut akan diteruskan ke Wemos D1 Mini yang mana tugas Wemos disini adalah sebagai interface untuk menyambungkan ke Aplikasi. Wemos D1 Mini mengirimkan data ke firebase dan akan muncul di Aplikasi yang ada pada smartphone. Dimana data tersebut diterima dari Wemos D1 Mini melalui koneksi internet wifi.

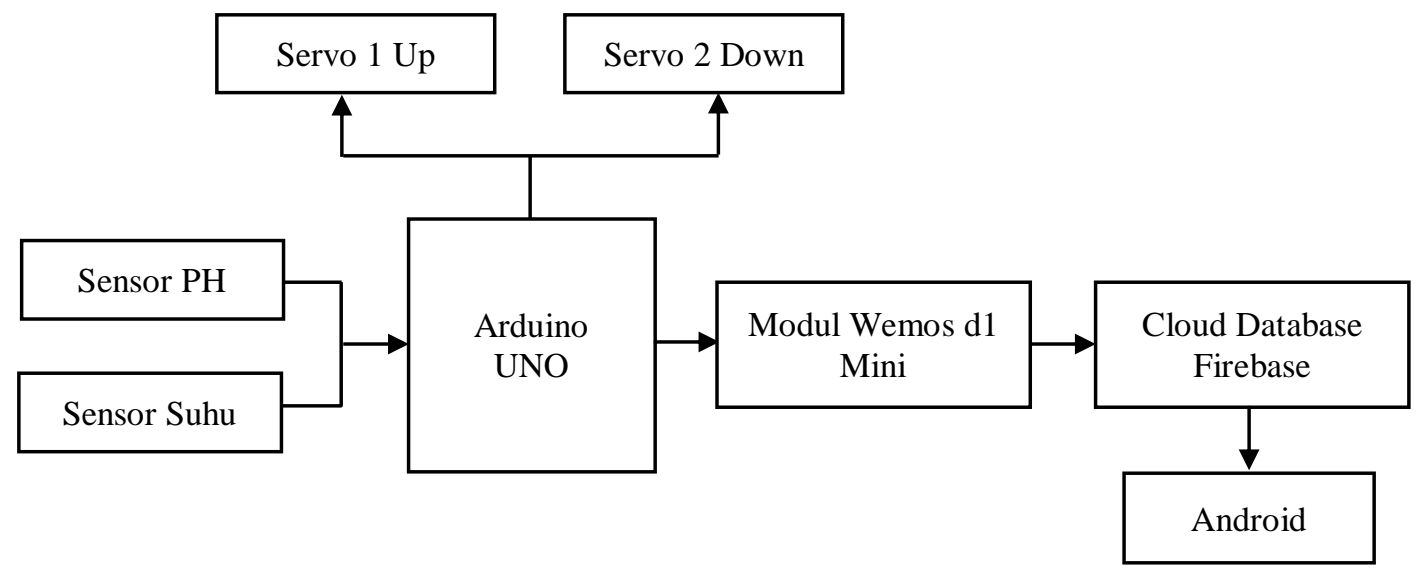

Gambar 1. Diagram blok sistem.

\subsection{Diagram Alur Sistem Monitoring PH dan Suhu Air}

Perancangan perangkat lunak pada penelitian ini, dijelaskan dalam diagram alur sistem monitoring $\mathrm{pH}$ dan suhu air sebagai sistematika dari perancangan alat. Gambar 2 menjelaskan proses monitoring $\mathrm{pH}$ dan suhu air. 


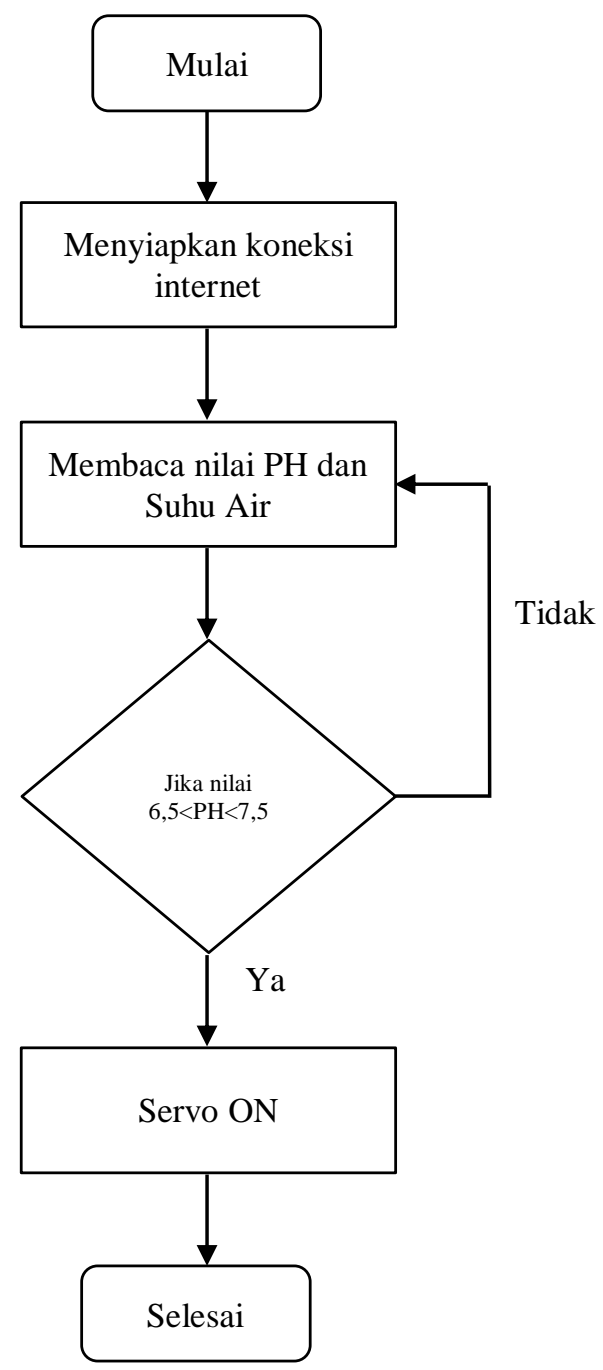

Gambar 2. Diagram alur sistem monitoring PH dan suhu air.

Proses awal yang dilakukan yaitu mengoneksikan wifi dengan smartphone, jika wifi sudah terhubung lalu diteruskan dengan membaca sensor $\mathrm{pH}$ dan jika tidak terhubung akan mengulangi proses koneksi. Jika sudah terbaca maka sensor mendeteksi nilai $\mathrm{pH}$ tersebut dan akan melakukan pengulangna jika tidak terdeteksi. Jika nilai $\mathrm{pH}$ sudah terbaca dan terdeteksi maka akan melanjutkan untuk membaca sensor suhu, Selanjutnya sistem menampilkan nilai $\mathrm{pH}$ dan suhu di smartphone. Sensor $\mathrm{pH}$ akan mendeteksi nilai dalam 3 kelompok yaitu jika nilai $\mathrm{pH}<6,5$ maka servo 1 on, jika pH > 7,5 maka servo 2 on, dan jika nilai $\mathrm{pH}$ diantara 6,6-7,4 maka servo 1 dan 2 off. Nilai yang sudah dikelompokan tersebut akan muncul di smartphone dan sistem otomatisasi dari servo akan bergerak sesuai dengan perintahnya. Kemudian hasil sensor suhu akan ditampilkan di smarthphone.

\subsection{Perancangan Perangkat Lunak}

Penelitian ini, menggunakan google firebase yang digunakan sebagai penyimpanan database. Firebase merupakan layanan database as a service yang menggunakan konsep real time dan firebase memberikan kelengkapan serta infrastruktur untuk membangun suatu aplikasi yang akan dibuat. 


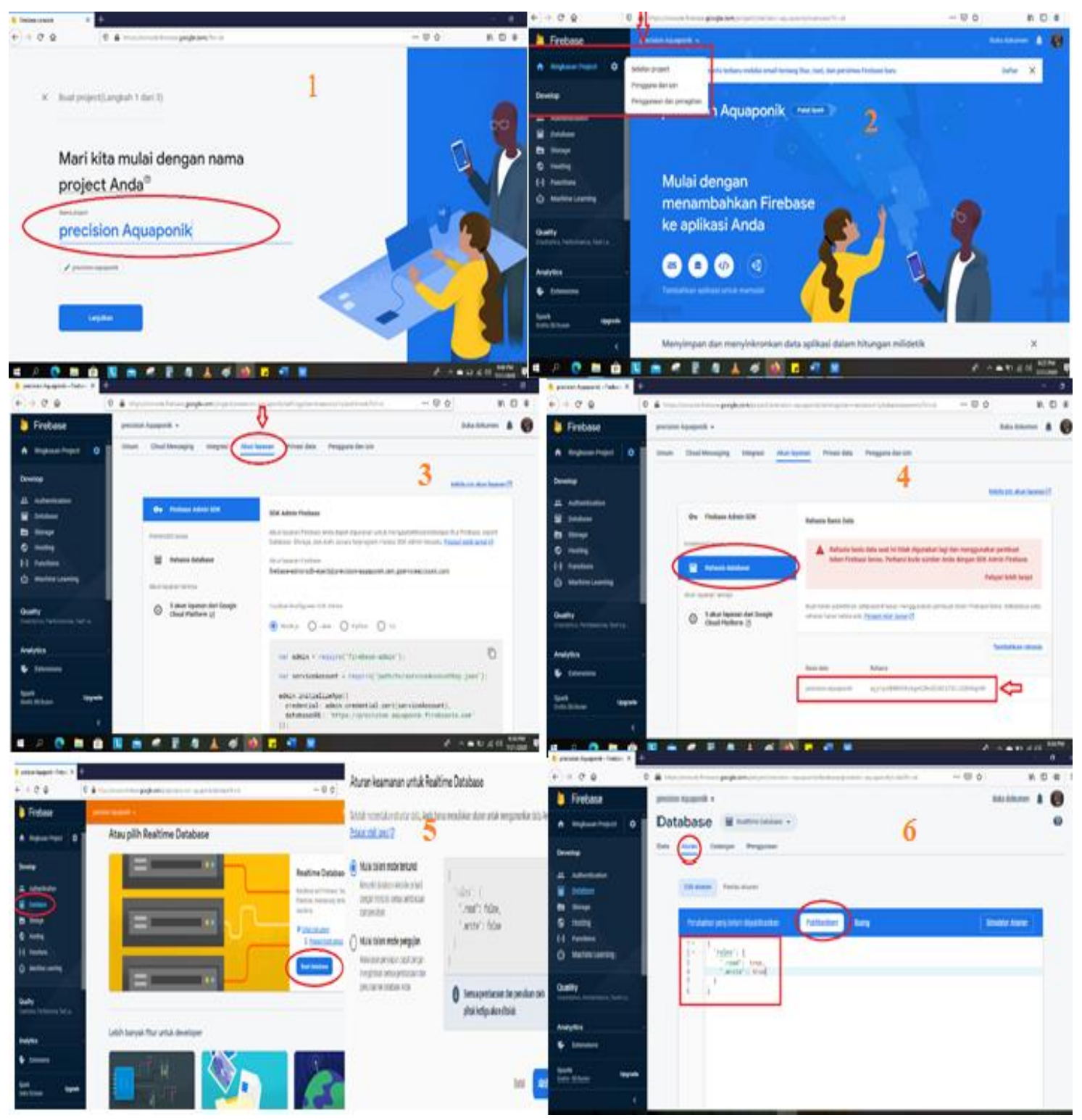

Gambar 3. Tampilan rahasia database pada akun layanan.

Gambar 3 merupakan rahasia database yang berfungsi untuk memunculkan kode rahasia yang digunakan untuk mengisi firebase authentication pada arduino IDE. Pada gambar kedua tampilan pembuatan Realtime Database, klik database lalu akan muncul tampilan Aturan Keamanan untuk Realtime Database pilih mulai dalam mode terkunci dan klik enable. Selanjutnya pada gambar ketiga tampilan awal realtime database lalu salin link yang ditandai dikotak merah untuk mengisi firebase token pada MIT App Inventor. Dan pada gambar ke-empat tampilan rules pada database merupakan aturan pemnacaan nilai yang dikirim ke database pada MIT App Inventor untuk membaca nilai yang ada pada firebase maka pilih rules, lalu ubah perintah yang "false" menjadi "true" lalu klik publish.

Selanjutnya desain aplikasi yang digunakan pada penelitian ini, menggunakan MIT App Inventor. MIT App Inventor bisa digunakan untuk pengguna baru tentang memprogram komputer dalam membuat aplikasi tanpa melakukan coding, karena hanya cukup melakukan dengan drag and drop objek. 


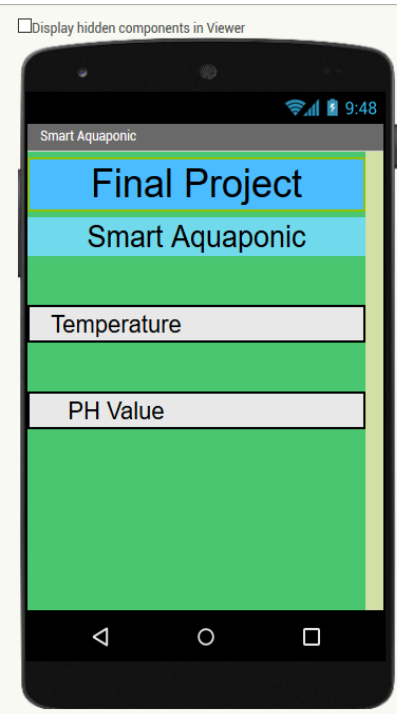

Gambar 4. Tampilan screen monitoring.

Gambar 4 merupakan tampilan untuk monitoring akuaponik pada alat yang akan dibuat. Dalam screen ini terdiri dari monitoring Temperature dan PH Value yang mana nantinya nilai dari suhu dan $\mathrm{pH}$ akan tampil pada tampilan tersebut.

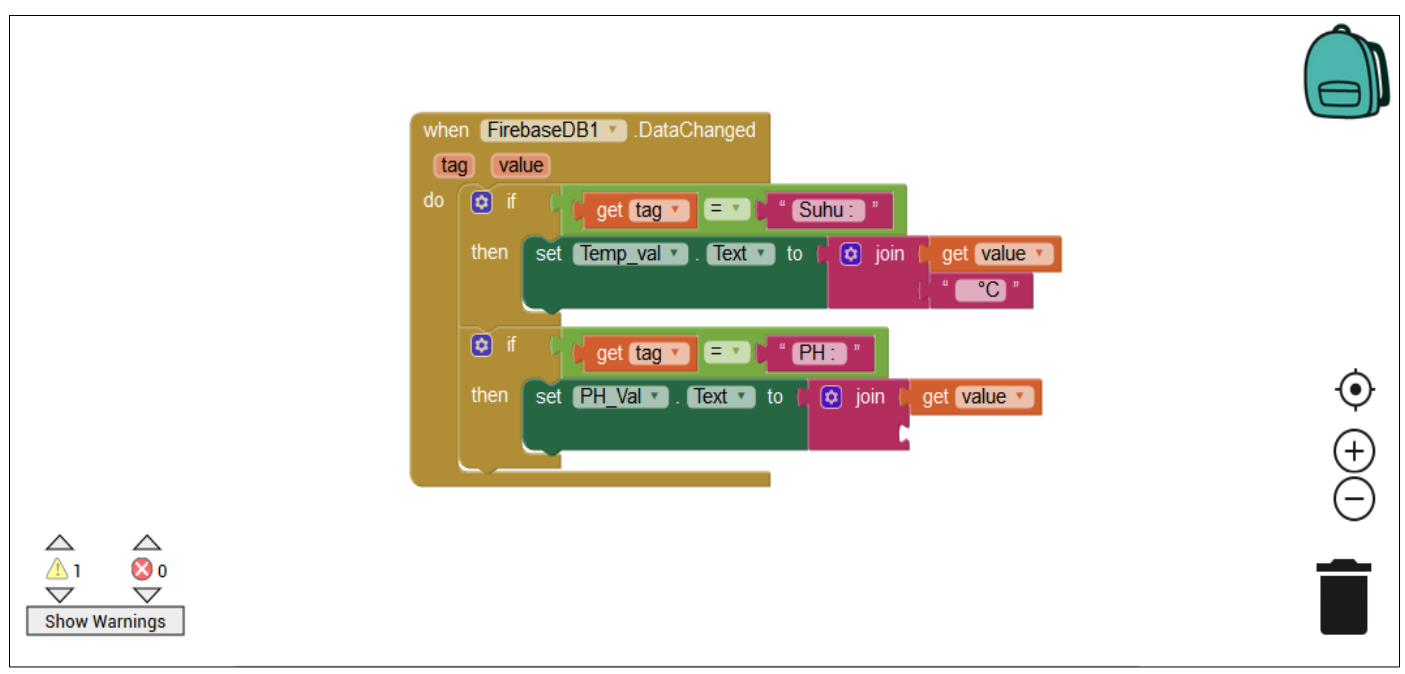

Gambar 5. Block screen aplikasi.

Gambar 5 merupakan tampilan untuk monitoring $\mathrm{pH}$ dan suhu dalam akuaponik pada alat yang akan dibuat. Dimana nilai yang didapat yang diambil dari database melalui firebase. Kemudian nilai Temperature dan $\mathrm{pH}$ value akan ditampilkan pada screen monitoring.

\section{Hasil dan Pembahasan}

\subsection{Pengujian Sensor pH}

Berikut merupakan hasil data dan analisa dari sensor pH dalam 3 kondisi untuk menguji pengukuran $\mathrm{pH}$ yaitu kondisi air asam, air murni, dan air basa.

a. Pengujian sensor $\mathrm{pH}$ Air Asam 


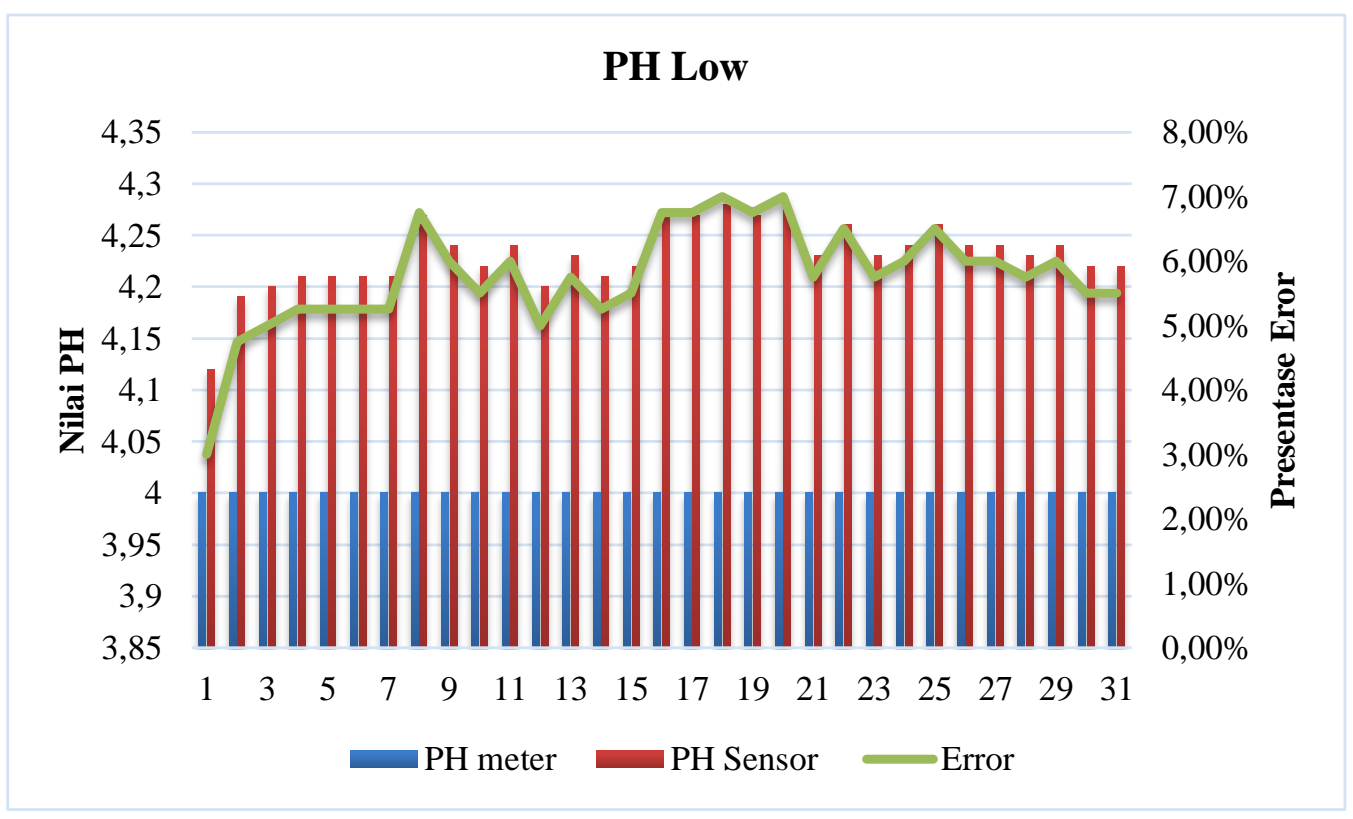

Gambar 6. Hasil grafik pengujian pH asam.

Gambar 6 merupakan hasil percobaan dengan menggunakan $\mathrm{pH}$ meter 4,00 dan hasil dari $\mathrm{pH}$ sensor pada serial monitor yang menunjukan angka tersebut tidak jauh berbeda. Kedua nilai $\mathrm{pH}$ yang diperoleh dari $\mathrm{pH}$ meter dan $\mathrm{pH}$ sensor dibandingkan untuk mengetahui nilai presentase kesalahan deteksi (error). Kesimpulan yang terdapat pada Gambar 6 yaitu percobaan yang diperoleh dari hasil pengukuran dengan larutan asam yang menunjukan nilai $<6,5$ dengan larutan asam menujukan rata-rata persentase error $5,77 \%$ yang artinya sensor tersebut bekerja dengan baik. Berdasarkan percobaan yang dilakukan di atas maka dapat dikatakan bahwa sensor $\mathrm{pH}$ dalam kondisi larutan asam sudah menunjukan bahwa sensor berfungsi dengan baik dengan hasik presentase eror yang kecil.

b. Pengujian Sensor pH Murni/medium

Gambar 7 merupakan hasil percobaan dengan menggunakan $\mathrm{pH}$ meter 6,5 dan hasil dari $\mathrm{pH}$ sensor pada serial monitor yang menunjukan angka tersebut tidak jauh berbeda. Kedua nilai $\mathrm{pH}$ yang diperoleh dari $\mathrm{pH}$ meter dan $\mathrm{pH}$ sensor dibandingkan untuk mengetahui nilai presentase kesalahan deteksi (error). Kesimpulan yang terdapat pada Gambar 7 yaitu pada percobaan yang diperoleh hasil pengukuran dengan larutan air murni yang menunjukan nilai 6,6-7,5. Hasil percobaan air murni menunjukan rata-rata persentase error 6,97\% yang artinya sensor tersebut bekerja dengan baik. Pada percobaan yang dilakukan diatas maka dapat dikatakan bahwa sensor $\mathrm{pH}$ dalam kondisi larutan air murni sudah menunjukan bahwa sensor berfungsi dengan baik dengan persentase error yang kecil. 


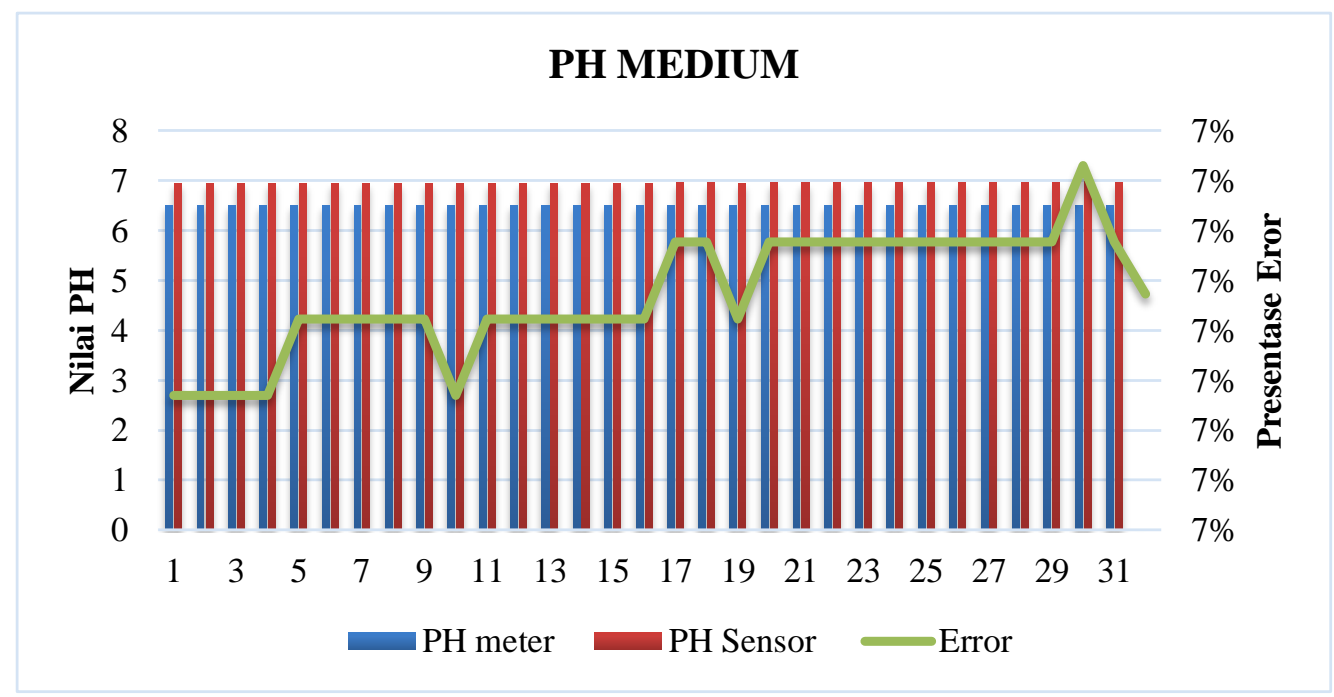

Gambar 7. Hasil grafik pengujian pH murni.

c. Pengujian sensor pH Basa

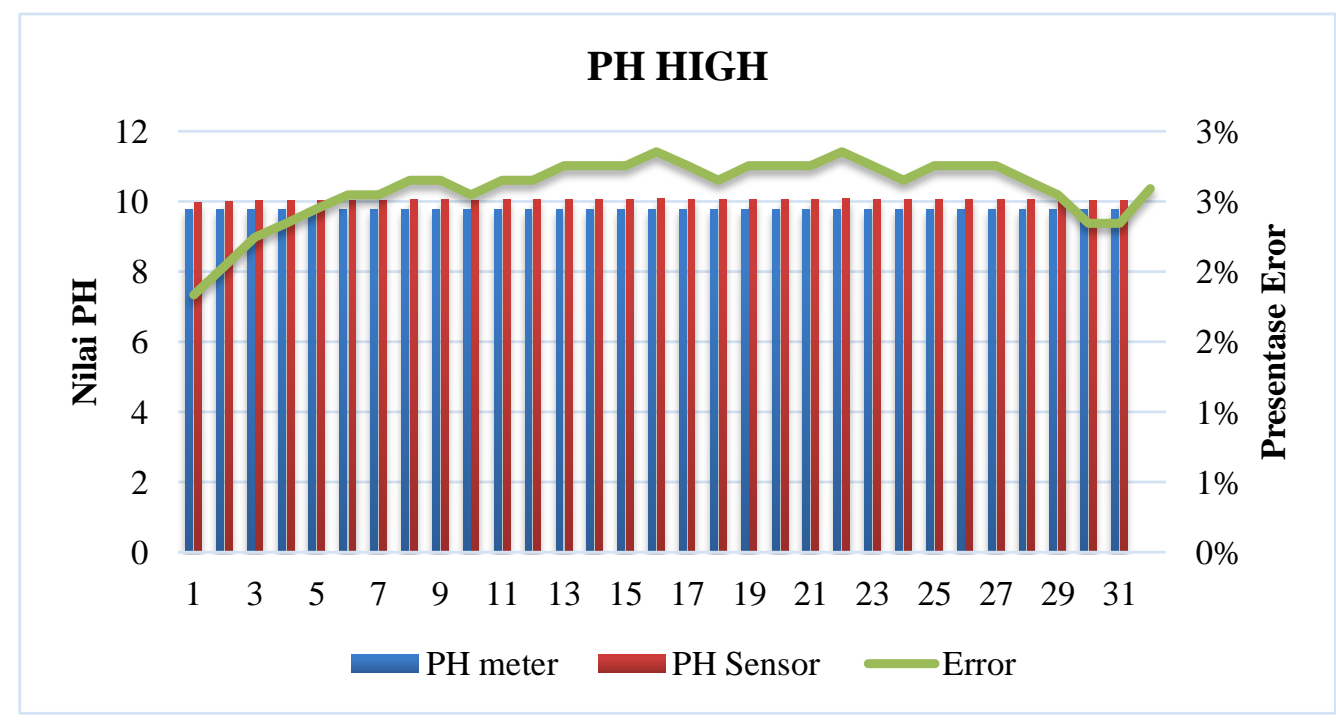

Gambar 8. Hasil grafik pengujian $\mathrm{pH}$ basa.

Gambar 8 merupakan hasil percobaan dengan menggunakan $\mathrm{pH}$ meter 9,8 dan hasil dari $\mathrm{pH}$ sensor pada serial monitor yang menunjukan angka tersebut tidak jauh berbeda. Kedua nilai $\mathrm{pH}$ yang diperoleh dari $\mathrm{pH}$ meter dan $\mathrm{pH}$ sensor dibandingkan untuk mengetahui nilai presentase kesalahan deteksi (error). Kesimpulan yang terdapat pada Gambar 8 yaitu pada percobaan yang diperoleh hasil pengukuran dengan larutan basa yang menunjukan nilai >7,5 menunjukan rata rata presentase error $2,59 \%$ yang artinya sensor tersebut bekerja dengan baik. Pada percobaan yang dilakukan diatas maka dapat dikatakan bahwa sensor $\mathrm{pH}$ dalam kondisi larutan basa sudah menunjukan bahwa sensor berfungsi dengaan baik dengan hasil presentase error yang kecil.

\subsection{Pengujian Sensor Suhu DS18b20}

Berikut merupakan hasil data dan analisa dari sensor suhu dengan 3 kondisi air untuk pengujian pengukuran suhu yaitu kondisi air panas, air netral, dan air dingin.

a. Pengujian Sensor Suhu Air Panas 


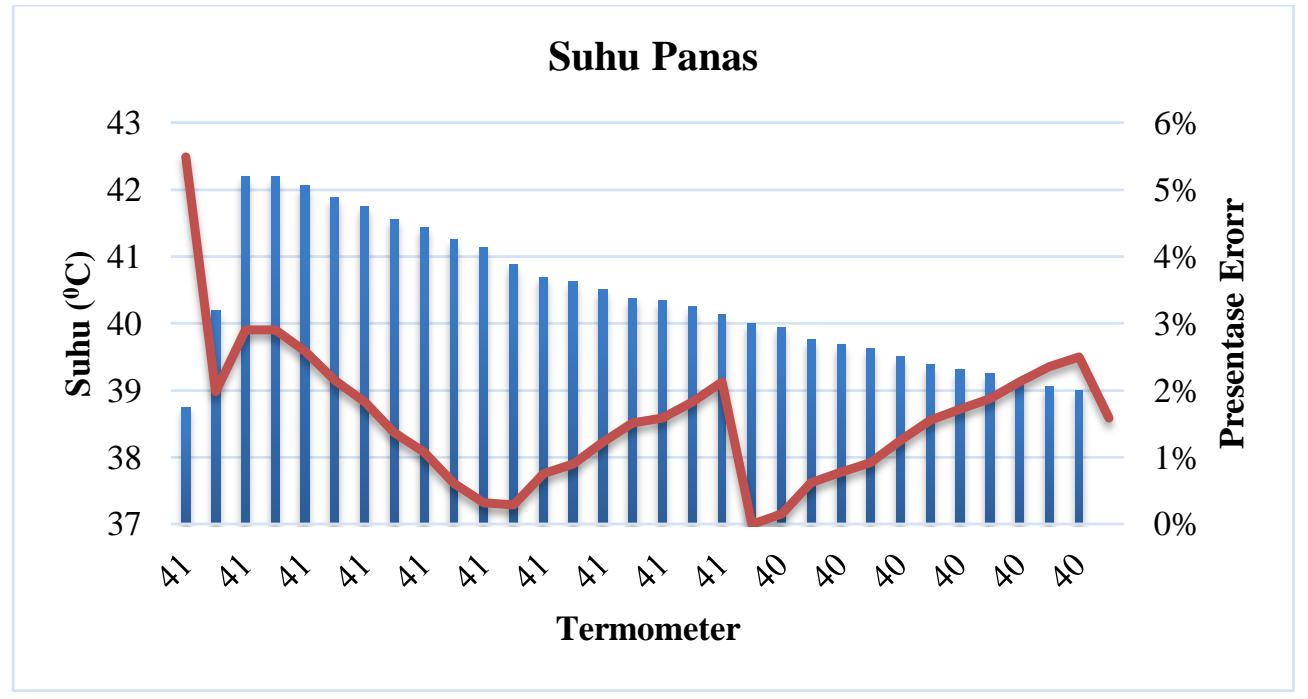

Gambar 9. Grafik pengujian air panas.

Gambar 9 merupakan hasil pengujian menggunakan air panas dengan menggunakan sensor suhu dallas ds18b20, dan termometer digunakan untuk memeriksa suhu secara akurat. Kedua nilai suhu yang diperoleh dari dallas ds18b20 dan termometer dibandingkan untuk mengetahui nilai presentase kesalahan deteksi (eror). Hasil yang tampil di monitor tidak jauh berbeda, hal tersebut menandakan bahwa alat bekerja dengan semestinya. Pada grafik menunjukan hasil presentase eror sebesar $1,59 \%$ yang artinya percobaan air panas diatas menunjukan bahwa sensor berfungsi dengan baik dengan hasil presentase eror yang kecil.

b. Pengujian Air Normal

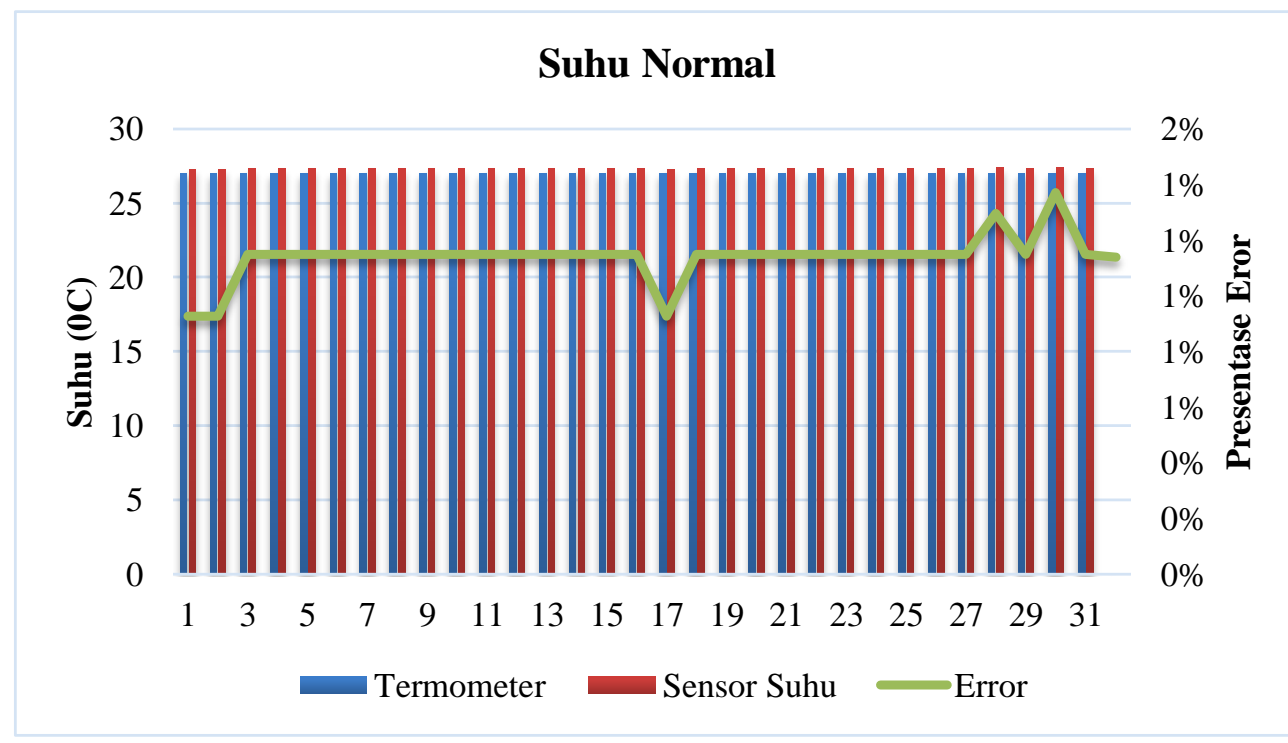

Gambar 10. Grafik air suhu normal.

Gambar 10 merupakan hasil pengujian menggunakan air normal dengan menggunakan sensor suhu Dallas ds18b20, dan termometer digunakan untuk memeriksa suhu secara akurat. Kedua nilai suhu yang diperoleh dari Dallas ds18b20 dan termometer dibandingkan untuk mengetahui nilai presentase kesalahan deteksi (error). Hasil yang tampil di monitor tidak jauh berbeda, hal tersebut menandakan bahwa alat bekerja dengan semestinya. Pada grafik 
menunjukan hasil presentase error sebesar $1,14 \%$ yang artinya percobaan air normal diatas menunjukan bahwa sensor berfungsi dengan baik dengan hasil presentase error yang kecil.

\section{c. Pengujian Sensor Suhu Air Dingin}

Gambar 11 diatas merupakan hasil pengujian menggunakan air dingin dengan menggunakan sensor suhu dallas ds18b20, dan termometer digunakan untuk memeriksa suhu secara akurat. Kedua nilai suhu yang diperoleh dari dallas ds18b20 dan termometer dibandingkan untuk mengetahui nilai presentase kesalahan deteksi (eror). Hasil yang tampil di monitor tidak jauh berbeda, hal tersebut menandakan bahwa alat bekerja dengan semestinya. Pada grafik menunjukan hasil presentase eror sebesar $1,02 \%$ yang artinya percobaan air dingin diatas menunjukan bahwa sensor berfungsi dengan baik dengan hasil presentase eror yang kecil.

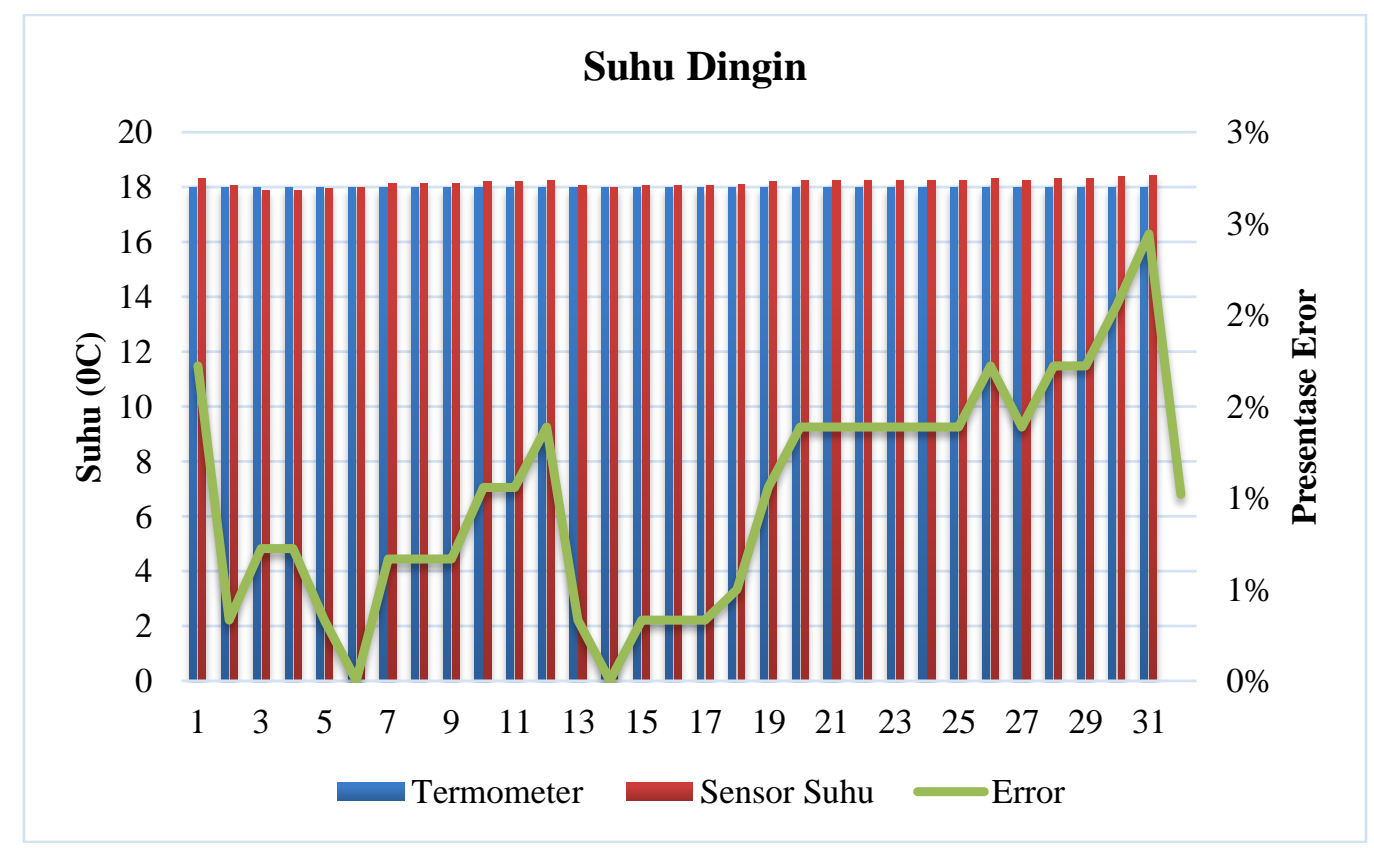

Gambar 11. Grafik pengujian air dingin.

\subsection{Pengujian Quality of Service (QoS)}

Pengujian delay yang dilakukan selama 30 kali percobaan sampai jarak $10 \mathrm{~m}$ menghasilkan delay yang berbeda. Pada percobaan delay tertinggi pada pengujian ke 25 dengan jarak $9 \mathrm{~m}$ dan jarak terkecil pada pengujian ke 3 dengan jarak $1 \mathrm{~m}$. Dapat disimpulkan bahwa pada pengujian delay ini banyaknya jumlah data yang dikirim tidak terlalu berpengaruh pada delay. 


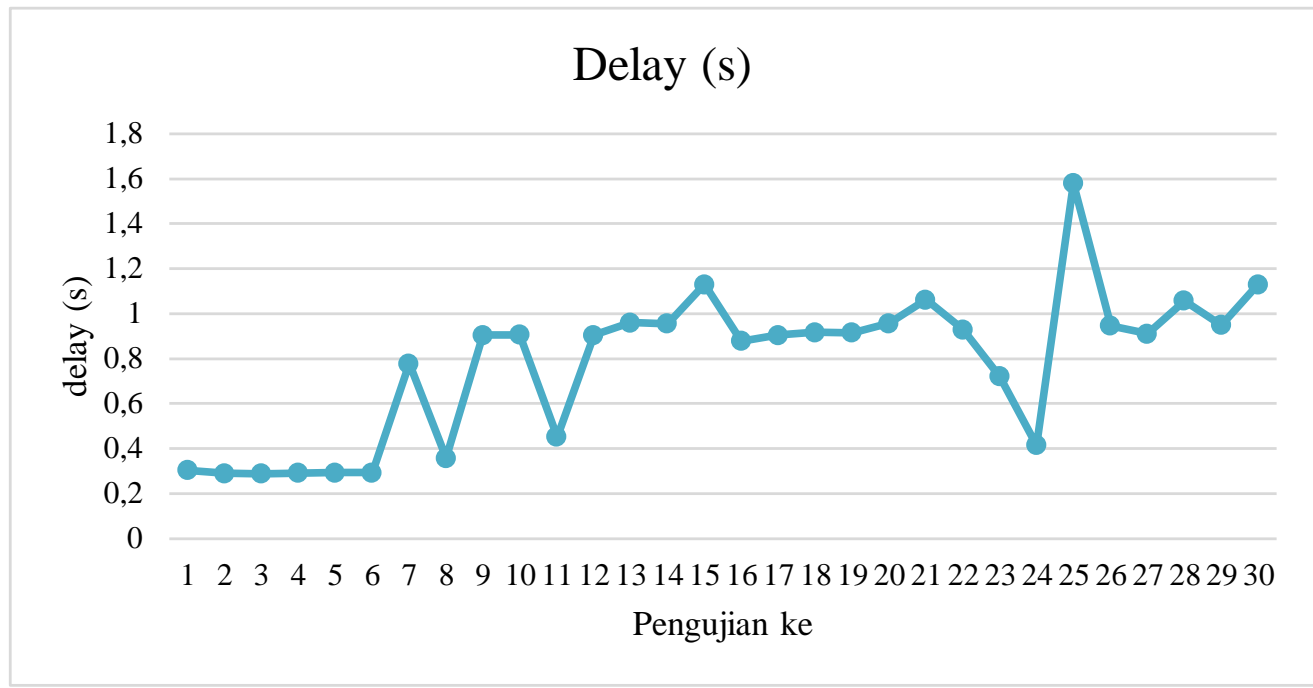

Gambar 12. Grafik pengujian delay.

Pengujian Throughput yang dilakukan selama 30 kali percobaan sampai jarak $10 \mathrm{~m}$ menghasilkan Throughput yang berbeda. Pengujian Throughput tertinggi pada jarak $1 \mathrm{~m}$ pengujian ke 3 dan terkecil pada jarak $10 \mathrm{~m}$ percobaan ke 28. Dapat disimpulkan bahwa pada pengujian Throughput ini besarnya jumlah data dan delay mempengaruhi nilai Throughput yang dihasilkan. Semakin besar jumlah data maka semakin besar pula Throughput yang dihasilkan.

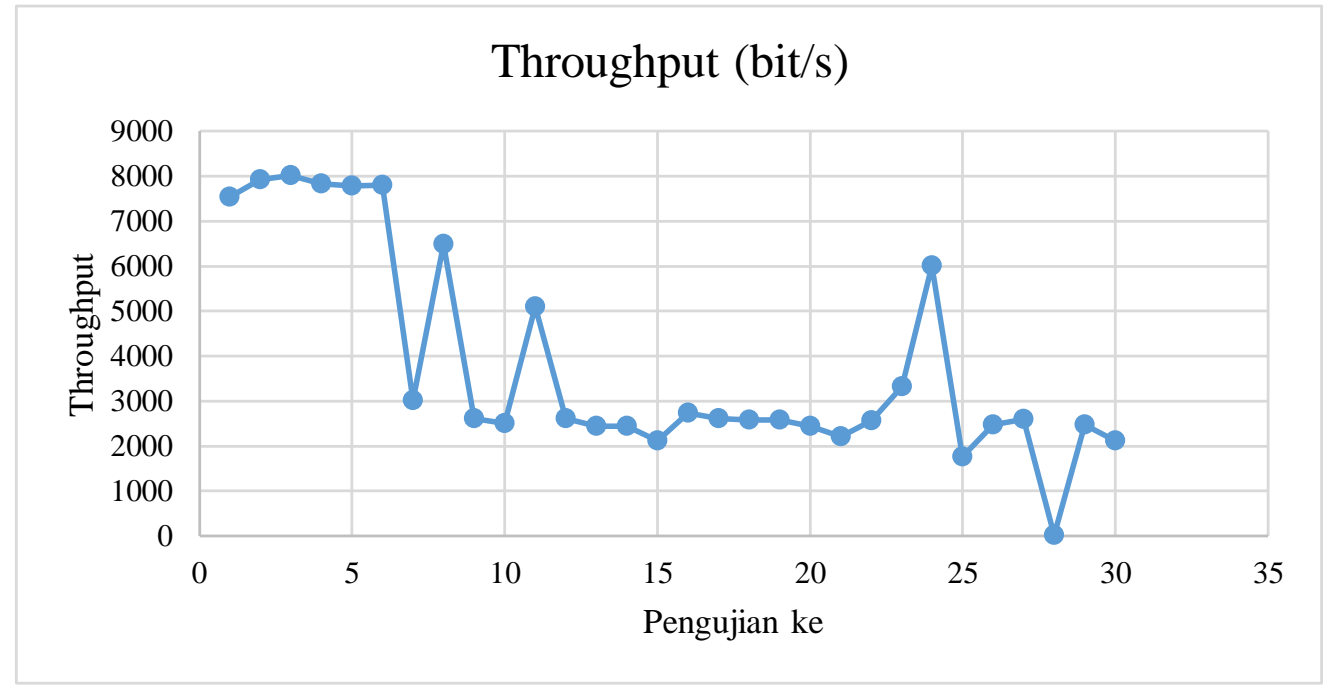

Gambar 13. Grafik pengujian throughput.

Pengujian packet loss yang dilakukan selama 30 kali percobaan sampai jarak $10 \mathrm{~m}$. jika jumlah data yang digunakan semakin besar maka semakin banyak jumlah paket yang ditampilkan. Jumlah data yang ditangkap tergantung pada jumlah data yang dikirimkan oleh Wemos D1 Mini, karena jarak disini berpengaruh terhadap parameter QoS. Packet loss yang dihasilkan setelah dilakukan beberapa kali percobaan memiliki hasil yang sama yaitu $0 \%$ yang menunjukan Wemos D1 Mini berhasil pengirimkan semua paket tanpa adanya loss. 


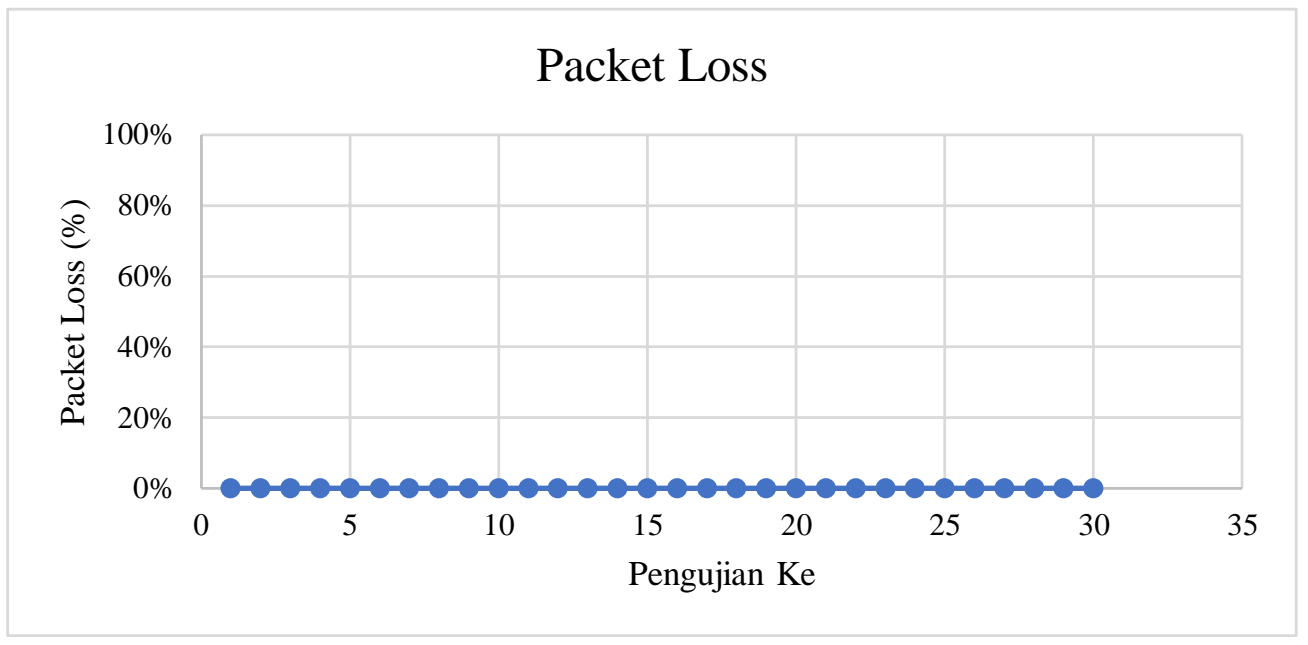

Gambar 14. Grafik pengujian packet loss.

\subsection{Pengujian Software}

Dari Tabel 1 menunjukan hasil pengujian monitoring $\mathrm{pH}$ pada software yang didapat dari hasil tampilan serial monitor dan hasil tampilan monitor aplikasi bahwa nilai yang didapat oleh sensor $\mathrm{pH}$ sama dan status yang di dapat yaitu berhasil dan didapatkan hasil akurasi $100 \%$, hal tersebut menunjukan bahwa pengujian software kali ini berhasil dan sensor bekerja pada semestinya.

Dari Tabel 2 menunjukan hasil pengujian monitoring suhu pada software yang didapat dari hasil tampilan serial monitor dan hasil tampilan monitor aplikasi bahwa nilai yang didapat oleh sensor suhu sama dan status yang di dapat yaitu berhasil dan didapatkan hasil akurasi 100\%, hal tersebut menunjukan bahwa pengujian software kali ini berhasil dan sensor bekerja pada semestinya.

Tabel 1. Pengujian Monitoring PH Pada Software

\begin{tabular}{cccc}
\hline No & Hasil Serial Monitor & Hasil Monitor Aplikasi & Status \\
\hline 1 & 6.94 & 6.94 & Berhasil \\
2 & 6.94 & 6.94 & Berhasil \\
3 & 6.94 & 6.94 & Berhasil \\
4 & 6.94 & 6.94 & Berhasil \\
5 & 6.95 & 6.95 & Berhasil \\
6 & 6.95 & 6.95 & Berhasil \\
7 & 6.95 & 6.95 & Berhasil \\
8 & 6.95 & 6.95 & Berhasil \\
9 & 6.95 & 6.95 & Berhasil \\
10 & 6.94 & 6.94 & Berhasil \\
\hline
\end{tabular}


Tabel 2. Pengujian Monitoring Suhu Air Pada Software

\begin{tabular}{cccc}
\hline No & Hasil Serial Monitor & Hasil Monitor Aplikasi & Status \\
\hline 1 & 27.25 & 27.25 & Berhasil \\
2 & 27.25 & 27.25 & Berhasil \\
3 & 27.31 & 27.31 & Berhasil \\
4 & 27.31 & 27.31 & Berhasil \\
5 & 27.31 & 27.31 & Berhasil \\
6 & 27.31 & 27.31 & Berhasil \\
7 & 27.31 & 27.31 & Berhasil \\
8 & 27.31 & 27.31 & Berhasil \\
9 & 27.31 & 27.31 & Berhasil \\
10 & 27.31 & 27.31 & Berhasil \\
\hline
\end{tabular}

\section{Kesimpulan}

Berdasarkan hasil perancangan dan pengujian pada penelitian ini diperoleh data dari pengujian sensor $\mathrm{pH}$ dengan 3 kondisi yaitu air asam presentase eror 5,77\%, air murni didapatkan presentase eror $6,97 \%$, dan kondisi air basa didapatkan presentase eorr sebesar 2,59\%. Kemudian untuk suhu dalam 3 kondisi juga yaitu kondisi air panas didapatkan eror 1,02\%, air normal 1,14\%, dan air dingin dengan eror 1,59\% dapat dilihat dari presentasee masing-masing eror yang kecil pada pengujian masing-masing sensor yang menunjukan sensor tersebut berfungsi dengan semestinya. Untuk pengujian QOS yaitu delay, throughput, dan packet loss sudah bekerja pada semestinya karena didapatkan hasil sesuai dengan yang diinginkan. Selanjutnya untuk pengujian monitoring $\mathrm{pH}$ dan suhu pada software dikatakan baik karena didapatkan akurasi $100 \%$ yang menunjukan bahwa pengujian tersebut berkerja pada semestinya. Dari hasil semua yang didapatkan maka alat berjalan dengan baik dan sesuai yang diinginkan.

\section{Ucapan Terima Kasih}

Terimakasih penulis sampaikan kepada seluruh pihak yang telah membantu proses penelitian dari awal hingga terselesaikan. Semoga penelitian ini dapat memberikan manfaat dan kontribusi di bidang elektronika.

\section{Referensi}

[1] A. Masduki, "Hidroponik Sebagai Sarana Pemanfaatan Lahan," J. Pemberdaya., vol. 1, no. 2, pp. 185-192, 2017.

[2] A. Fahmi, I. A. Wijaya, N. A. Ghani, and A. Sugiharto, "Sistem Monitoring Dan Controlling Air Nutrisi Aquaponik Menggunakan Arduino Uno Berbasis Web Server," Kinetik, vol. 1, no. 1, pp. 39-46, 2016.

[3] Y. Sastro, "Akuaponik: Budidaya Tanaman Terintegrasi Dengan Ikan, Permasalahan Keharaan dan Strategi Mengatasinya," Bul. Pertan. Perkota., vol. 5, no. 1, pp. 33-42, 2015.

[4] K. R. Haqim, I. Agus, G. Permana, and U. S. St, "Perancangan Web Monitoring Dan Kontroling Aquaponic Untuk Budidaya Ikan Lele Berbasis Internet Of Things," ISSN 2442-5826 e-Proceeding Appl. Sci. Vol.4, No.3 Desember 2018|, vol. 4, no. 3, pp. 2786$2808,2018$.

[5] Zulfiadi dan Suraiya Nazlia, "Pengaruh tanaman berbeda pada sistem akuaponik terhadap tingkat kelangsungan hidup dan pertumbuhan benih ikan lele (Clarias sp)," Acta Aquat., vol. 1, no. 1, pp. 24-30, 2014.

[6] F. Karoba, R. Nurjasmi, U. Respati, and I. Jakarta, "Pengaruh Perbedaan pH terhadap Pertumbuhan dan Hasil Tanaman Kailan (Brassica oleraceae) Sistem Hidroponik Nft 
(Nutrient Film Tecnique)," J. Ilm. Respati, vol. 7, no. 2, pp. 5-6, 2015.

[7] L. E. Rahmadhani, L. I. Widuri, and P. Dewanti, "Kualitas Mutu Sayur Kasepak (Kangkung, Selada, dan Pakcoy)," J. Agroteknologi, vol. 14, no. 01, pp. 33-43, 2020.

[8] S. R. Fitriani, E. Daningsih, and Yokebed, "Pengaruh Perbedaan Konsentrasi Fosfor terhadap Pertumbuhan Kangkung Darat (ipomoea reptans) pada Hidroponik Super Mini," J. Pendidik. dan Pembelajaran, vol. 6, no. 5, pp. 1-10, 2017.

[9] H. arnita ayu kusunamawati, djoko suprapto, "Pengaruh Ekoenzim Terhadap Kualitas Air Dalam Pembersaran Ikan Lele,” J. of Maquares, vol. 7, no. 1992, pp. 1-11, 2012.

[10] K. Oktavianto, "Perencanaan dan Pembuatan Alat Pengatur Suhu, Monitoring Ph Air dan Pemberi Makan Ikan Arwana Otomatis Berbasis Mikrokontroler Atmega16," vol. 1, no. 1, 1945.

[11] D. Muhammad Hasan Basri, "Rancang Bangun Sistem Akuaponik Berbasis Mikrokontroler dan Android," J. Simetrik, vol. 9, no. 2, pp. 208-214, 2019.

[12] A. Qalit and A. Rahman, "Rancang Bangun Prototipe Pemantauan Kadar Ph Dan Kontrol Suhu Serta Pemberian Pakan Otomatis Pada Budidaya Ikan Lele Sangkuriang Berbasis Iot," J. Karya Ilm. Tek. Elektro, vol. 2, no. 3, pp. 8-15, 2017.

[13] E. Rohadi et al., "Sistem Monitoring Budidaya Ikan Lele Berbasis Internet Of Things Menggunakan Raspberry Pi," J. Teknol. Inf. dan Ilmu Komput., vol. 5, no. 6, p. 745, 2018. 